\title{
REALITAS PENGGUNAAN BAHASA INDONESIA RAGAM TULISAN PADA LEMBAGA PEMERINTAHAN
}

\author{
(THE REALITY OF USING WRITTEN INDONESIAN LANGUAGE \\ ATTHE OFFICE OF GOVERNMENT)
}

\author{
Akmaluddin \\ Universitas Islam Negeri Mataram \\ Jalan Pendidikan Nomor 35 Mataram \\ Pos-el: akmal@uinmataram.ac.id
}

Diterima: 9 April 2018; Direvisi: 9 Mei 2018; Disetujui: 21 Mei 2018

\begin{abstract}
Abstrak
Salah satu fungsi bahasa Indonesia adalah sebagai bahasa negara. Atas dasar fungsi tersebut, bahasa Indonesia digunakan dalam penyusunan dokumen-dokumen kedinasan di berbagai lembaga pemerintahan. Ragam bahasa Indonesia yang seharusnya digunakan dalam penyusunan dokumen kedinasan pada berbagai lembaga pemerintahan adalah bahasa Indonesia standar. Namun, harapan ini belum sepenuhnya terlaksana karena masih terdapat banyak kesalahan berbahasa tulisan dalam penyusunan dokumen kedinasan. Oleh karena itu, penelitian ini dilakukan untuk mengetahui bentukbentuk kesalahan berbahasa dalam dokumenkedinasan di Sekda Pemkot Mataram. Pengumpulan data dalam penelitian ini dilakukan dengan metode observasi dan dokumentasi. Analisis data dilakukan dengan teknik kode dan pengkodean. Kesalahan bahasa tulisan yang ditemukan pada dokumen dinas tersebut sebanyak 27 yang terdiri atas kesalahan dalam bidang EYD yang meliputi: kesalahan penggunaan huruf kapital, kesalahan penggunaan tanda titik, kesalahan penggunaan tanda koma, dan kesalahan penggunaan cetak miring. Setelah diakumulasi, kesalahan dalam bidang EYD sebanyak 15 kesalahan. Sementara itu, kesalahan dalam bidang morfologi sebanyak 6, kesalahan dalam bidang sintaksis sebanyak 3, dan kesalahan dalam bidang semantik sebanyak 3 kesalahan.
\end{abstract}

Kata kunci: analisis, kesalahan berbahasa tulisan, naskah dinas

\begin{abstract}
One of Indonesian function is state language. On the based of the function, Indonesian used in compilation of official texts in various state institutes. Indonesian manner which ought to be used in compilation of official texts is standard Indonesian language. But, this order not yet is fully executed because still there are a lot of mistake of have written language in compilation of official texts. Therefore, this research is conducted to know forms written language errors in the official texts at the Secretariat Office of the Government of Mataram City.Data collecting in this research is conducted with observation method and documentation. While data analysis conducted with code and code technique. Written language errors of found at official texts counted 27 which consist of mistake in the field of EYD covered: mistakeof usage of letter of kapital, mistake usage of dot sign, mistake usage of semicolon sign, and mistake usage of italic letter. Latter accumulated mistake of EYD counted 15 mitakes. Meanwhile, mistake morphology counted 6, mistake of syntax counted 3, and mistake of semantics counted 3.
\end{abstract}

Keyword: analyse, mistake of use written language, document on duty 


\section{Pendahuluan}

Bahasa Indonesia sebagai
bahasa nasional sekaligus sebagai
bahasa negara harus ditempatkan sesuai
dengan peranan dan kedudukannya.

Sebagai bahasa negara, bahasa Indonesia memiliki peranan yang secara khusus diatur dalam UUD 1945 bab XV pasal 36 yang menyatakan bahwa bahasa negara adalah bahasa Indonesia. Adapun salah satu fungsi bahasa Indonesia sebagai bahasa negara adalah sebagai bahasa resmi kenegaraan. Dalam kaitannya dengan fungsi ini, bahasa Indonesia seharusnya dipergunakan dalam administrasi kenegaraan, misalnya, dokumendokumen, keputusan, surat-menyurat, baik yang dikeluarkan oleh pemerintah maupun lembaga negara lainnya.

Dasar hukum penggunaan bahasa Indonesia sebagai bahasa resmi kenegaraan adalah UU Nomor 24 Tahun 2009 pasal 27 yang menyebutkan bahwa bahasa Indonesia wajib digunakan dalam dokumen resmi negara. Pasal tersebut secara gamblang tentang kewajiban menggunakan bahasa Indonesia dalam dokumen resmi. Dokumen-dokumen resmi sepatutnya disusun dengan bahasa Indonesia yang baik dan benar serta tidak mengandung banyak kesalahan berbahasa. Penggunaan bahasa Indonesia yang baik dan benar pada dokumen resmi kenegaraan sebagaimana yang diharapkan peraturan perundangan-undangan tersebut ditunjang oleh adanya Peraturan Menteri Pendidikan dan Kebudayaan Republik Indonesia Nomor 50 Tahun 2015 tentang Pedoman Umum Ejaan Bahasa Indonesia (PUEBI). Permendikbud ini secara rinci mengatur berbagai kaidah kebahasaan yang dapat dijadikan rujukan dalam penggunaan bahasa Indonesia, khususnya ragam tulisan.

Adanya aturan khusus mengenai penggunaan bahasa Indonesia sebagai bahasa negara ini seharusnya menjadi kewajiban lembaga negara untuk selalu menggunakan bahasa Indonesia sesuai kaidah yang telah ditentukan, khususnya dalam bahasa tulisan. Namun, aturan ini tidak serta-merta membuat lembaga negara menerapkan kaidah bahasa Indonesia tersebut. Dalam penggunaannya, kesalahankesalahan berbahasa dalam dokumen atau naskah dinas masih dijumpai. Bentuk kesalahan berbahasa yang dapat ditemukan pada naskah-naskah dinas sangat bervariasi, misalnya kesalahan 
dalam bidang morfologi, kesalahan dalam bidang sintaksis, baik berupa kesalahan pada frasa maupun kesalahan pada klausa, kesalahan dalam bidang semantik, dan kesalahan dalam hal penggunaan ejaan. Semua bentuk kesalahan tersebut harus diperbaiki sesuai kaidah, khususnya dalam naskah dinas lembaga-lembaga pemerintahan sebagai wujud pelaksanaan aturan fungsi bahasa Indonesia sebagai bahasa negara. Salah satu lembaga pemerintahan yang menjadi sasaran penelitian ini adalah Pemerintah Kota Mataram (selanjutnya disebut Pemkot Mataram).

Pemkot Mataram merupakan salah satu lembaga negara di tingkat kota yang disejajarkan dengan pemerintah kabupaten. Pemkot Mataram terdiri atas beberapa bagian yang diketuai oleh seorang asisten yang membidangi berbagai elemen. Dalam praktiknya, Pemkot Mataram tentu memiliki perangkat atau naskah kedinasan yang harus dibuat dengan bahasa Indonesia standar. Naskah dinas yang dimaksud dapat berupa laporan kegiatan, pidato kenegaraan, dan suratmenyurat, baik yang sifatnya internal maupun eksternal. Kesalahan yang terdapat dalam naskah dinas tersebut tentunya digolongkan ke dalam bahasa tulisan.

Kesalahan bahasa tulisan pada naskah dinas di lembaga-lembaga pemerintahan tidak sepatutnya diabaikan. Hal ini berarti perlu dilakukan perbaikan terhadap kesalahan bahasa tulisan yang ada untuk menghindari kesalahan yang sama pada lembaga pemerintahan lainnya. Perbaikan kesalahan ragam tulisan pada lembaga pemerintahan dapat melibatkan berbagai pihak, misalnya lembaga yang secara khusus memiliki tugas pokok dan fungsi membina dan mengembangkan bahasa Indonesia, kalangan akademisi yang tentunya berlatar belakang pendidikan kebahasaan, misalnya dosen, ahli kebahasaan, dan pemerhati bahasa lainnya.

\section{Kerangka Teori}

\subsection{Penggunaan Bahasa Indonesia dalam Dokumen Resmi}

Aturan perundang-undangan secara jelas dan tegas menyatakan kewajiban penggunaan bahasa Indonesia yang baik dan benar pada berbagai bidang, salah satunya pada dokumen resmi kenegaraan. Kewajiban 
ini ditegaskan dalam UU Nomor 24 Tahun 2009 pasal 27 yang menyebutkan bahwa bahasa Indonesia wajib digunakan dalam dokumen resmi negara. Selain itu, ditegaskan pula dalam pasa 30 yang menyatakan bahwa bahasa Indonesia wajib digunakan dalam pelayanan administrasi publik di instansi pemerintahan.

Kewajiban penggunaan bahasa Indonesia pada dokumen dan administrasi publik di instansi pemerintahan ini diperkuat dengan adanya Peraturan Menteri Pendidikan dan Kebudayaan Republik Indonesia Nomor 50 Tahun 2015 tentang Pedoman Umum Ejaan Bahasa Indonesia. Permendikbud ini diharapkan menjadi acuan dalam penggunaan bahasa Indonesia terutama dalam ragam tulisan karena peraturan tersebut telah mengatur secara detail penggunaan unsur-unsur kebahasaan.

Penggunaan bahasa Indonesia pada dokumen resmi ini juga diatur oleh peraturan perundang-undangan lain yaitu Peraturan Pemerintah Republik Indonesia Nomor 57 Tahun 2014 tentang Pengembangan, Pembinaan, dan Pelindungan Bahasa dan Sastra, Serta Peningkatan Fungsi Bahasa
Indonesia. Selain itu ada pula Peraturan Presiden Republik Indonesia Nomor 16 Tahun 2010 tentang Penggunaan Bahasa Indonesia dalam Pidato Resmi Presiden dan/atau Wakil Presiden serta Pejabat Negara Lainnya.

Semua aturan perundangundangan ini menegaskan pentingnya penggunaan bahasa Indonesia pada forum resmi kenegaraan serta pelayanan administrasi publik lainnya. Ragam bahasa Indonesia yang digunakan dalam berbagai forum dan administrasi tersebut tentunya harus menggunakan bahasa Indonesia yang baik dan benar.

\subsection{Analisis Kesalahan Berbahasa}

Analisis dapat didefinisikan sebagai penyelidikan terhadap suatu peristiwa yang dapat berupa karangan atau perbuatan untuk mengetahui keadaan yang sebenarnya (KBBI, 2008). Definisi di atas mengandung makna bahwa dalam proses melakukan analisis terdapat aktivitas penyelidikan dengan maksud mengetahui keadaan sebenarnya. Aktivitas penyelidikan ini tentunya dilengkapi dengan tahapantahapan kerja yang prosedural yaitu: pertama, mengklasifikasikan kesalahan berbahasa berdasarkan tataran 
kebahasaan, misalnya bidang fonologi, morfologi, sintaksis, wacana, atau semantic; kedua, mengurutkan kesalahan berbahasa tersebut berdasarkan frekuensi kemunculannya dalam suatu karya; ketiga, menggambarkan letak kesalahan dan memperkirakan penyebab kesalahan tersebut; dan keempat, mengoreksi kesalahan tersebut serta merekomendasikan solusi perbaikan atas keslahan tersebut (Tarigan dan Sulistyaningsih, 1998).

Berdasarkan definisi di atas, dapat dibuat rumusan tentang analisis kesalahan berbahasa yaitu suatu kegiatan penelaahan terhadap penggunaan bahasa untuk mengetahui keadaan yang sebenarnya pada bahasa yang dianalisis. Berdasarkan pengertian ini dapat diketahui tujuan analisis kesalahan berbahasa adalah mencari dan menentukan landasan perbaikan terhadap kesalahan berbahasa pada aspek-aspek kebahasaan. Dalam artikel ini, penggunaan bahasa yang dianalisis adalah bahasa tulisan pada naskah dinas di Sekretariat Daerah Pemerintah Kota Mataram.

\subsection{Ruang Lingkup Analisis Kesalahan Berbahasa}

Kegiatan analisis kesalahan berbahasa merupakan kegiatan yang kompleks, baik dari segi tahapan pelaksanaannya maupun bidang kajiannya. Sebagaimana yang telah dijelaskan di atas, analisis kesalahan berbahasa memiliki prosedur kerja yang perlu diikuti. Bidang kajian yang perlu dianalisis dalam kegiatan analisis kesalahan berbahasa tulisan adalah bidang morfologi, bidang sintaksis, baik berupa frasa maupun klausa, bidang semantik, dan penggunaan ejaan bahasa Indonesia. Bidang kajian analisis kesalahan berbahasa tulisan tersebut akan dijelaskan pada uraian di bawah ini.

Morfologi adalah bagian dari ilmu bahasa yang membicarakan atau yang mempelajari seluk-beluk bentuk kata serta pengaruh perubahanperubahan bentuk kata terhadap golongan dan arti kata (Ramlan, 2001). Kesalahan berbahasa dalam bidang morfologi sebagian besar berkaitan dengan bahasa tulis. Kesalahan berbahasa dalam bidang morfologi dapat dikelompokkan menjadi kelompok afiksasi, reduplikasi, dan gabungan kata atau kata majemuk. 
Afiksasi berkaitan dengan penentuan bentuk asal, luluh dan tidaknya suatu fonem, penentuan variasi atau alomorf suatu morfem, dan penulisan morfem. Reduplikasi berkaitan dengan pengulangan bentuk dasar sehingga menghasilkan bentuk gramatik yang baru. Reduplikasi berkaitan dengan cara penulisan dan penentuan bentuk dasar yang diulang. Sedangkan gabungan kata atau kata majemuk adalah gabungan dua buah morfem dasar atau lebih yang mengandung satu pengertian baru (Haster, 2000). Analisis kesalahan berbahasa pada bidang kata majemuk berkaitan dengan cara penulisan kata majemuk. Berdasarkan proses perpaduannya, kata majemuk ada yang ditulis serangkai dan ada pula yang ditulis terpisah.

Frasa adalah satuan gramatikal yang berupa gabungan kata yang bersifat nonpredikatif, atau lazim juga disebut gabungan kata yang mengisi salah satu fungsi sintaksis di dalam kalimat. (Chaer, 2007). Berdasarkan pengertian yang dikemukakan Chaer di atas, dapat ditarik simpulan bahwa frasa pasti terdiri atas lebih dari satu kata. Hal ini juga telah dirumuskan oleh Shalima dkk, (2013) yang menyebutkan bahwa frasa adalah gabungan dua kata atau lebih yang bersifat nonpredikatif dan menduduki fungsi yang sama dalam kalimat, misalnya subjek, predikat, atau objek. Analisis kesalahan berbahasa yang berkaitan dengan bidang frasa dapat disebabkan oleh berbagai hal yaitu pengaruh bahasa ibu, salah susunan, berlebihan atau mubazir, penggunaan kata depan yang tidak tepat, salah pengulangan, penambahan kata tertentu pada frasa yang unsurnya tak terpisahkan, dan penghilangan kata tertentu yang menghubungkan bagianbagian frasa.

Sintaksis atau yang sering disebut kalimat adalah satuan bahasa terkecil dalam wujud lisan atau tulisan, yang mengungkapkan pikiran yang utuh (Alwi dkk, 2003). Kesalahan berbahasa dalam bidang sintaksis juga sering terjadi dalam kegiatan berbahasa sehari-hari sebagaimana kesalahan berbahasa pada bidang-bidang yang lain. Penyebab kesalahan dalam bidang sintaksis pun beragam. Adapun penyebab kesalahan berbahasa dalam bidang sintaksis dijelaskan oleh Tarigan dan Sulistyaningsih, (1998) yaitu: pengaruh bahasa ibu, lingkungan, kebiasaan, dan kesadaran penutur bahasa itu sendiri. Kesalahan berbahasa dalam berbagai bidang dan dalam 
berbagai situasi sepatutnya tidak dibiarkan berlarut-larut. Artinya, kesalahan berbahasa tersebut perlu diperbaiki.

Semantik adalah suatu istilah yang digunakan untuk bidang linguistik yang mempelajari hubungan antara tanda-tanda linguistik dengan hal-hal yang ditandainya (Chaer, 2002). Kesalahan berbahasa dalam bidang semantik ditandai oleh beberapa hal sebagaimana yang disebutkan Patteda (dalam Tarigan dan Sulistyaningsih, 1998). Indikator-indikator tersebut yaitu tidak dapat menjelaskan makna yang dimaksud pembicara atau penulis, tidak dapat menggunakan kata-kata dalam kalimat sesuai dengan makna dan fungsinya, serta tidak dapat menyebutkan sinonim dan antonim kata yang memang pasangannya (Tarigan dan Sulistyaningsih, 1998).

Selain dalam beberapa aspek kebahasaan di atas, kesalahan berbahasa juga berpotensi terjadi dalam hal penggunaan Ejaan Bahasa Indonesia Yang Disempurnakan (EYD). Ejaan adalah kaidah cara menggambarkan bunyi dalam bentuk tulisan (huruf) serta penggunaan tanda baca (KBBI, 2008). Berdasarkan makna kamus di atas, dapat ditarik simpulan bahwa ejaan bahasa Indonesia yang disempurnakan adalah seperangkat kaidah yang mengatur penggunaan bahasa Indonesia yang baku dalam bahasa tulis maupun bahasa lisan. Bahasa Indonesia memiliki sejarah pembakuan ejaan selama dua kali sehingga ditetapkannya penggunaan Ejaan Bahasa Indonesia Yang Disempurnakan (Chaer, 2007). Analisis kesalahan berbahasa tulis dalam bidang penggunaan ejaan terdiri atas beberapa hal, yaitu pemakaian huruf, penulisan kata, pemakaian tanda baca, dan penulisan unsur serapan (Haimun, 2014). Semua aspek yang disebutkan Haimun di atas menjadi objek kajian dalam penelitian ini.

\section{Metode Penelitian}

\subsection{Pendekatan Penelitian}

Pendekatan yang digunakan dalam penelitian ini adalah pendekatan kualitatif deskriptif karena penelitian ini bertujuan untuk memberikan gambaran atau deskripsi tentang suatu keadaan secara objektif. Sumber data dalam penelitian ini adalah penggunaan bahasa tulisan pada dokumen kedinasan di Sekretariat Daerah Pemerintah Kota 
Mataram. Data dalam penelitian ini dikumpulkan dengan metode dokumentasi dan metode simak.

\subsection{Populasi Penelitian}

Populasi dalam penelitian ini adalah dokumen kedinasan yang dikeluarkan oleh Sekretariat Daerah Pemkot Mataram. Dokumen-dokumen tersebut berupa surat-menyurat, misalnya surat keputusan, surat undangan, permakluman, surat perintah, memo, laporan kegiatan, naskah pidato, dan dokumen-dokumen lain yang ada. Mengingat Sekretariat Daerah Pemkot Mataram memiliki dokumen kedinasan yang sangat banyak, perlu dilakukan pembatasan terhadap populasi penelitian ini. Dengan demikian, penelitian ini merupakan penelitian sampel (Arikunto, 2013). Pembatasan populasi ini dimaksudkan sebagai sampling yaitu pengambilan sebagian populasi atau semesta sebagai wakil populasi yang dianggap representatif. Penentuan sampel ini lebih lanjut dibahas pada subbagian di bawah ini.

\subsection{Sampel Penelitian}

Teknik sampling yang digunakan dalam penelitian ini adalah random sampling yaitu teknik penentuan sampel secara acak. Mengingat dokumen kedinasan di Sekretariat Daerah Pemerintah Kota Mataram begitu banyak sehingga dokumen kedinasan yang dianalisis adalah dokumen kedinasan apa pun yang masih ada dan menjadi arsip Sekretariat Daerah Pemkot Mataram. Dalam hal ini, sampel data berupa surat dinas, buku panduan, dan laporan yang dikeluarkan oleh lembaga di bawah Sekretariat Daerah Pemerintah Kota Mataram.

\subsection{Jenis dan Wujud dan Data}

Jenis data dalam penelitian ini berupa data kualitatif yaitu data yang tidak berupa angka melainkan deskripsi penggunaan bahasa tulisan pada dokumen kedinasan di Sekda Pemkot Mataram. Ditinjau dari sumbernya, data dalam penelitian ini merupakan data internal karena diperoleh dari instansi yang menggambarkan penggunaan bahasa tulisan pada organisasi tersebut yakni Sekda Pemkot Mataram. Dengan demikian, data dalam penelitian ini jika ditinjau dari aspek cara memperolehnya, data penelitin ini merupakan data primer karena dikumpulkan sendiri oleh peneliti secara langsung dari objek yang diteliti. 
Adapun wujud data dalam penelitian ini adalah dokumendokumen kedinasan di lingkungan Sekretariat Daerah Pemkot Mataram, baik berupa surat dinas, buku panduan, laporan, dan lain sebagainya. Data-data ini kemudian dianalisis untuk mendapatkan deskripsi penggunaan bahasa ragam tulisan pada lembaga tersebut. Analisis dilakukan dengan menggunakan teori-teori analisis kesalahan berbahasa.

\subsection{Pengumpulan Data}

Pengumpulan data dalam penelitian ini dilakukan dengan dua cara yaitu metode dokumentasi dan teknik simak. Dokumentasi dimaksudkan bahwa dalam penelitian ini perlu diadakan pengumpulan atau pendokumentasian dokumen-dokumen kedinasan yang akan dijadikan sebagai data penelitian. Dokumen kedinasan yang menjadi sumber data dalam penelitian ini didokumentasi sehingga memudahkan dalam pemilihan dan pemilahan data. Selanjutnya setelah data-data tersebut didokumentasikan, dilakukan pencatatan untuk bentukbentuk kesalahan berbahasa tulisan yang ada.

\subsection{Analisis Data}

Analisis data dalam penelitian ini dilakukan dengan teknik kode dan pengkodean dengan mengikuti langkahlangkah berikut: (1) persiapan, (2) klasifikasi data berdasarkan jenis kesalahan berbahasa yang ditemukan, dan (3) penerapan data sesuai dengan pendekatan penelitian. Analisis data dilakukan dengan mencermati kesalahan berbahasa tulisan pada naskah dinas di Sekretariat Daerah Pemkot Mataram dan diuji dengan teori-teori Analisis Kesalahan Berbahasa Indonesia.

\section{Pembahasan}

\subsection{Kesalahan Berbahasadalam Bidang EYD}

Kesalahan berbahasa dalam bidang EYD yang terdapat pada dokumen kedinasan di Sekda Pemkot Mataram terdiri atas beberapa bentuk sebagaimana terurai dalam penjelasan di bawah ini.
1. Kesalahan Penggunaan Huruf Kapital

Kesalahan penggunaan huruf kapital banyak ditemukan pada dokumen kedinasan di Sekda Pemkot 
Mataram sebagaimana dirincikan sebagai berikut.

\section{a. Perihal: Permohonan Saksi \\ b. Perihal: Rapat Pembahasan Perwal c. Perihal: Klarifikasi dan Register Raperda}

Penggunaan huruf kapital pada perihal surat di atas tidak tepat karena tidak sesuai dengan kaidah. Kaidah menyebutkan bahwa huruf kapital dipakai sebagai huruf pertama kata pada awal kalimat. Kesalahan pada perihal surat tersebut dapat diperbaiki menjadi kalimat berikut.

a.1 Perihal: Permohonan saksi

b.1 Perihal: Rapat pembahasan Perwal

c.1 Perihal: Klarifikasi dan register Raperda

Selain pada perihal surat di atas, penggunaan huruf kapital yang tidak tepat juga tampak pada rincian waktu pelaksanaan rapat sesuai penggalan surat berikut.

d. ...untuk hadir dalam persidangan yang akan diselenggarakan pada:

Hari/Tanggal : Selasa, 15 April 2014

Waktu : 10.00 wita - Selesai

Tempat : PTUN Mataram

Agenda : Mendengarkan

keterangan saksi

Penggunaan huruf kapital pada kata Hari/Tanggal, Waktu, Tempat, Agenda dan Mendengarkan tidak tepat karena tidak sesuai dengan kaidah. Kata-kata tersebut merupakan kelanjutan dari kalimat sebelumnya dan bukan merupakan awal sebuah kalimat sehingga harus ditulis dengan huruf kecil. Rincian tersebut dapat diperbaiki dengan menggunakan huruf kecil pada awal kata Hari/Tanggal, Waktu, Tempat, Agenda, Selesai dan Mendengarkan sehingga tampak pada perbaikan berikut.

d.1 ...untuk hadir dalam persidangan yang akan diselenggarakan pada:

hari, tanggal : Selasa, 15 April 2014

waktu : 10.00 wita - selesai

tempat : PTUN Mataram

agenda : mendengarkan keterangan saksi

Kesalahan penggunaan huruf kapital juga tampak pada penggalan surat yang dibuat oleh Bagian Hukum Pemkot Mataram berikut ini.

e. ...instansi saudara yang secara Tupoksi menangani perizinan...

Pada penggalan surat di atas, terdapat dua kesalahan berbahasa yang terkait dengan kaidah penggunaan huruf kapital. Kesalahan tersebut yaitu penggunaan huruf kecil pada kata sapaan saudara dan penggunaan huruf kapital pada kata tupoksi di tengah kalimat. Kedua kata tersebut tidak sesuai kaidah. Seharusnya, huruf 
kapital dipakai sebagai huruf pertama kata penunjuk hubungan kekerabatan seperti bapak, ibu, saudara, kakak, adik, dan paman yang dipakai dalam penyapaan dan pengacuan. Dengan demikian, perbaikan kalimat tersebut menjadi kalimat e.1 berikut.

\section{e.1 ...instansi Saudara yang secara tupoksi menangani perizinan...}

Bentuk kesalahan penggunaan huruf kapital yang lain dapat dilihat pada penggalan surat yang ditulis oleh Bagian Pemerintahan, Sekretaris Daerah, dan Bagian PDEI berikut.

f. Dalam rangka penerimaan Kunjungan Kerja DPRD Kabupaten...

g. Kami merekomendasikan Pengadaan 1 Unit Printer...

h. ...telah disediakan layanan publik melalui menu Kritik dan Saran...

Kata-kata yang tercetak miring pada penggalan surat di atas tidak tepat karena menggunakan huruf kapital di tengah kalimat. Agar menjadi tepat, kalimat tersebut dapat diperbaiki dengan kalimat berikut ini.

f.1 Dalam rangka penerimaan kunjungan kerja DPRD Kabupaten...

g.1 Kami merekomendasikan pengadaan satu unit printer...

h.1 ...telah disediakan layanan publik melalui menu kritik dan saran...
Kesalahan penggunaan huruf kapital tidak hanya terdapat pada surat dinas di Sekda Pemkot Mataram, tetapi terdapat juga pada laporan kegiatan yang ditulis oleh beberapa bagian di lingkup Sekda Pemkot Mataram. Misalnya, tampak pada penggalan laporan yang ditulis oleh Bagian Organisasi berikut.

i. Tujuan Kegiatan memberikan pemahaman teknis tentang Penyusunan Indikator Kinerja kepada aparatur Pemerintah Kota Mataram sehingga mampu menyusun indikator kinerja secara benar.

Kata bercetak miring pada penggalan laporan tersebut tidak tepat karena menggunakan huruf kapital di tengah kalimat. Perbaikan kesalahan kata pada penggalan laporan tersebut dapat dilakukan dengan menggunakan huruf kecil pada kata bercetak miring. Perbaikan tersebut tampak pada kalimat berikut.

i. Tujuan Kegiatan

memberikan pemahaman teknis tentang penyusunan indikator kinerja kepada aparatur Pemerintah Kota Mataram sehingga mampu menyusun indikator kinerja secara benar.

2. Kesalahan Penggunaan Tanda Titik

Kesalahan berbahasa tulis dalam hal penggunaan tanda juga 
banyak terjadi pada penulisan gelar akademik. Kesalahan tersebut tampak pada kutipan surat berikut.

a. Mataram, 8 Mei 2014 a.n. Sekda Assisten Tata Praja

\section{Lalu Indra Bangsawan, SH}

Penulisan gelar akademik pada kutipan surat di atas tidak tepat karena tidak sesuai dengan kaidah. Seharusnya, tanda titik digunakan untuk memisahkan setiap unsur singkatan gelar akademik. Dengan demikian, perbaikan kesalahan di atas dapat dilakukan dengan membubuhkan tanda titik pada setiap unsur gelar akademik sehingga menjadi a.1 di bawah ini.

a.1 Mataram, 8 Mei 2014

a.n. Sekda Assisten Tata Praja

Lalu Indra Bangsawan, S.H.

3. Kesalahan Penggunaan Tanda Koma

Kesalahan penggunaan tanda koma tampak pada kutipan surat yang dikeluarkan oleh Bagian Administrasi dan Pengendalian Pembangunan Sekda Pemkot Mataram berikut ini.

Oleh karena itu diminta kepada setiap penyelenggara...

Kutipan surat tersebut tidak tepat karena tidak sesuai dengan kaidah.
Salah satu kaidah penggunaan tanda koma yaitu dipakai di belakang ungkapan atau kata penghubung antara kalimat yang terdapat pada awal kalimat. Termasuk di dalamnya, oleh karena itu, jadi, lagi pula, meskipun begitu, akan tetapi. Dengan demikian, perbaikan kesalahan tersebut dapat dilakukan seperti pada a.1 di bawah ini.

Oleh karena itu, diminta kepada setiap penyelenggara...

4. Kesalahan Penulisan Huruf Miring

Kesalahan lain yang berkaitan dengan EYD yang terdapat dalam naskah dinas Sekda Pemkot Mataram adalah kesalahan dalam penulisan huruf miring. Bentuk kesalahan yang ditemukan adalah sebagai berikut:

a. mencerminkan good governance dan clean governance...

b. memberikan username dan password...

c. silakan menghubungi helpdesk kami...

Kesalahan berbahasa tulisan dalam bidang penggunaan huruf miring terdapat pada ketiga kutipan di atas. Kesalahan tersebut disebabkan tidak menggunakan huruf miring pada kosakata bahasa asing. Kaidah yang seharusnya adalah huruf miring dalam cetakan dipakai untuk menuliskan kata 
nama ilmiah atau ungkapan asing kecuali yang telah disesuaikan ejaannya. Berdasarkan kaidah tersebut, kesalahan penggunaan huruf miring pada poin a-c di atas dapat dilakukan seperti rincian berikut.

a.1 mencerminkan good governance dan clean governance...

b.1 memberikan username dan password...

c.1 silakan menghubungi helpdesk kami...

\subsection{Kesalahan Berbahasa Tulisan dalam Bidang Morfologi}

Bentuk-bentuk kesalahan

berbahasa tulisan yang ditemukan pada naskah dinas di Sekda Pemkot Mataram tampak pada rincian berikut.

a. Tingkat partisipasi perempuan dalam pembangunan memiliki korelasi dengan tingkat harmonisasi rumah tangga, sehingga kekerasan dalam rumah tangga harus diminimalisir.

Pada penggalan kalimat di atas terdapat kesalahan morfologi yaitu pada kata diminimalisir. Bentuk -ir, -or, -ur merupakan bentuk terikat bahasa asing yang bermakna keadaan dan dapat pula bermakna pelaku. Dengan demikian, kata bercetak miring pada kalimat tersebut dapat diganti dengan bentuk lain yang lebih tepat yaitu diminimalisasi atau dengan memilih diksi yang lain misalnya dikurangi. Kesalahan pada kalimat di atas dapat diperbaiki menjadi bentuk berikut.

a.1 Tingkat partisipasi perempuan dalam pembangunan memiliki korelasi dengan tingkat harmonisasi rumah tangga sehingga kekerasan dalam rumah tangga harus diminimalisasi.

a.2 Tingkat partisipasi perempuan dalam pembangunan memiliki korelasi dengan tingkat harmonisasi rumah tangga sehingga kekerasan dalam rumah tangga harus dikurangi.

Bentuk kesalahan dalam bidang morfologi yang lain tampak pada kata bercetak miring pada kedua kalimat berikut.

b. Memperhatikan jumlah kasus KDRT yang cenderung meningkat, telah dilakukan langkah strategis dalam perlindungan dan pencegahan KDRT

c. Guna meningkatkan ketersediaan kawasan resapan air, Badan Lingkungan Hidup Kota Mataram melalui Program Perlindungan dan Konservasi Sumber Daya Alam, akan menambah cakupan Biopori.

Dalam kalimat tersebut, terdapat kata perlindungan. Bentuk tersebut merupakan bentuk yang tidak tepat sehingga harus diganti dengan bentuk turunan yang tepat yaitu pelindungan. 
d. ...menyebabkan tiap daerah aliran sungai tersebut menjadi daerah rawan longsor terutama di musim penghujan.

Pada kalimat di atas, terdapat kata bercetak miring yang tidak tepat secara morfologis yaitu kata penghujan. Kata tersebut merupakan kata bentukan dari kata dasar hujan yang mendapat awalan peN- sehingga menjadi penghujan. Namun penggunaan bentuk tersebut tidak tepat karena dapat menimbulkan makna yang tidak sesuai dengan pesan yang ingin disampaikan dalam kalimat tersebut. Imbuhan peNmemiliki beberapa makna yaitu: (a) yang melakukan; alat untuk melakukan, (b) yang menjadi; menjadikan, (c) yang menggunakan; memakai, (d) yang membuat; yang menghasilkan, (e) yang mengeluarkan (suara), (f) yang memberi; melengkapi dengan, (g) yang menuju, (h) yang mencari, (i) yang berprofesi atau yang biasa melakukan. Berdasarkan makna tersebut, bentuk penghujan merupakan kata bentukan yang tidak tepat karena tidak dapat dimaknai sebagaimana kaidah tersebut. Perbaikan atas kesalahan tersebut dapat dilakukan dengan menggunakan kata dasar yaitu hujan. e. Salah satu dampak abrasi pantai adalah terjadinya intrusi air laut yang dapat mempengaruhi kondisi air tanah di wilayah Kota Mataram.

Kesalahan lain dalam bidang morfologi tampak pada kata bercetak miring kalimat di atas. Dalam kalimat tersebut terdapat kata mempengaruhi yang merupakan kata bentukan dari imbuhan me-i dan kata dasar pengaruh. Setiap kata dasar yang berawalan huruf $k, t, p, s$ yang diikuti huruf vokal, huruf $k, \quad t, \quad p, s$ tersebut akan luluh jika mendapat awalan meN-. Dengan demikian, kata mempengaruhi pada kalimat di atas harus diganti dengan kata memengaruhi. Perbaikan kalimat tersebut tampak pada kalimat e.1 di bawah ini.

e.1 Salah satu dampak abrasi pantai adalah terjadinya intrusi air laut yang dapat memengaruhi kondisi air tanah di wilayah Kota Mataram.

Selain kesalahan-kesalahan di atas, kesalahan lain dalam bidang morfologi yang ditemukan pada dokumen dinas di Sekda Pemkot Mataram adalah penggunaan kata bentuk permukiman sebagaimana tampak pada kalimat $f$ di bawah ini. 
f. ...dibutuhkan tiga komponen penting yaitu Jalan, Drainase, dan Permukiman.

Kata bercetak miring tersebut merupakan hasil bentukan dari afiks peN-an dan kata dasar mukim yang berjenis kata kerja. Kata bentukan permukiman sama dengan kata pemandian, pemakaman yang terbentuk dari afiks peN-an dan kata dasar mandi dan makam yang samasama berkelas kata kerja. Atas dasar itu, kata permukiman seharusnya menjadi pemukiman karena memiliki imbuhan dan kelas kata dasar yang sama dengan kata mandi dan makam. Perbaikan kalimat tersebut tampak pada $f .1$ di bawah ini.

f.1 ...dibutuhkan tiga komponen penting yaitu jalan, drainase, dan pemukiman.

\subsection{Kesalahan Berbahasa Tulisan dalam Bidang Sintaksis}

Bentuk-bentuk kesalahan

berbahasa dalam bidang sintaksis yang ditemukan pada dokumen kedinasan di Sekda Pemkot Mataram dapat dilihat pada rincian berikut ini.

a. Memperhatikan proses PTUN dalam gugatan nomor: 2/G/2014/PTUN.MTR yang diajukan oleh Fahruddin, dkk yang akan memasuki agenda keterangan saksi, untuk itu diharapkan memerintahkan kepada PNS pada instansi saudara untuk hadir dalam...

Penggalan surat yang dikeluarkan oleh Bagian Hukum Sekda Pemkot Mataram di atas tidak tepat karena pola kalimat yang digunakan tidak jelas. Artinya, kalimat tersebut tidak memiliki pokok kalimat yakni subjek melainkan langsung diawali dengan predikat dan diikuti keterangan akibat. Selain itu kalimat tersebut terlalu panjang sehingga mengaburkan fungsi unsur-unsur kalimat tersebut. Oleh karena itu, seharusnya kalimat tersebut dipecah menjadi dua kalimat sehingga struktur kalimatnya tidak rancu. Perbaikan kesalahan sintaksis kalimat tersebut tampak pada a.1 di bawah ini.

a.1 Kami informasikan bahwa proses PTUN dalam gugatan nomor: 2/G/2014/PTUN.MTR yang diajukan oleh Fahruddin, dkk akan memasuki agenda keterangan saksi. Untuk itu, Saudara diharapkan memerintahkan kepada PNS pada instansi saudara untuk hadir dalam...

b. Dengan telah dikeluarkannya peraturan Kepala BKN tentang Penilaian Pretasi Kerja PNS maka DP3 sudah tidak dipergunakan lagi dan digantikan dengan Penilaian Pretasi Kerja PNS. 
Kutipan kalimat di atas merupakan kalimat majemuk yang digunakan dalam dokumen surat yang dibuat oleh Bagian Organisasi Sekda Pemkot Mataram. Kalimat di atas merupakan kalimat majemuk karena pada dasarnya kalimat tersebut terdiri atas dua pola. Namun, kalimat di atas tidak tepat karena kedua pola kalimat tersebut berstatus sebagai anak kalimat sedangkan kalimat majemuk adalah kalimat yang terdiri atas induk kalimat dan anak kalimat. Anak kalimat ditandai dengan kata dengan dan maka. Dengan demikian, perbaikan kesalahan kalimat di atas dapat dilakukan dengan menghilangkan salah satu kata keterangan tersebut sehingga menjadi kalimat berikut.

b.1 Dengan telah dikeluarkannya peraturan Kepala BKN tentang Penilaian Pretasi Kerja PNS, DP3 sudah tidak dipergunakan lagi dan digantikan dengan Penilaian Pretasi Kerja PNS

Kesalahan lain yang termasuk kesalahan sintaksis adalah ketiadaan unsur inti dalam suatu kalimat. Kalimat yang baik minimal memiliki unsur subjek dan predikat. Ketiadaan salah satu unsur tersebut terlihat pada penggalan surat berikut. c. Mengharapkan kehadiran Bapak/Ibu dalam Rapat Koordinasi terkait Standar Satuan Harga, yang akan dilaksanakan pada:

Kalimat di atas langsung diawali dengan unsur predikat dan tidak memiliki unsur subjek. Perbaikan kalimat tersebut agar memenuhi persyaratan kalimat yang baik dapat dilakukan dengan menambahkan unsur subjek dalam kalimat tersebut sehingga menjadi kalimat berikut ini.

c.1 Dengan ini kami mengundang Bapak/Ibu dalam Rapat Koordinasi terkait Standar Satuan Harga, yang akan dilaksanakan pada:

\subsection{Kesalahan Berbahasa Tulisan dalam Bidang Semantik}

Berikut ini bentuk kesalahan semantik yang terdapat dalam dokumen kedinasan di Sekda Pemkot Mataram.

a. Asisten Tata Praja yang membawahi dan mengkoordinasikan Bagian Hukum...

b. Asisten Perekonomian Pembangunan, yang membawahi Bagian Perekonomian...

c. Asisten Administrasi Umum, yang membawahi Bagian Umum...

Kata bentukan membawahi sejajar dengan kata bentukan mengatasi. Masing-masing terdiri atas morfem meng + kata dasar $+i$ sehingga terbentuklah kata membawahi dan mengatasi. Kelas kata dasar pada kedua 
kata bentukan tersebut sama-sama nomina, imbuhan yang melekatinya pun sama sehingga makna yang ditimbulkan sama. Makna yang ditimbulkan pada kedua kata tersebut adalah ada di bawah dan ada di atas (Arifin, 2010).

Berdasarkan kalimat (a), (b), dan (c) di atas, penggunaan kata membawahi jelas tidak tepat karena kedudukan asisten berada di bawah bagian tersebut. Padahal, dalam struktur pemerintahan Pemkot Mataram, kedudukan asisten di atas bagian. Ringkasnya, perbaikan makna kalimat tersebut dapat dilakukan dengan membuat kalimat sebagai berikut.
a.1 Asisten Tata Praja yang mengatasi dan mengkoordinasikan Bagian Hukum... atau
a.2 Bagian Hukum membawahi dan mengkoordinasikan Asisten Tata Praja
b.1 Asisten Perekonomian Bagian Perekonomian... atau Pembangunan, yang mengatasi
b.2 Bagian Perekonomian membawahi AsistenPerekonomian Pembangunan
c.1 Asisten Administrasi Umum, yang mengatasi Bagian Umum... atau
c. 2 Bagian Umum membawahi Asisten Administrasi Umum

\subsection{Faktor-Faktor Penyebab Kesalahan Berbahasa Tulisan pada Naskah Dinas di Sekretariat Daerah Pemkot Mataram}

Kesalahan-kesalahan berbahasa tulis, termasuk kesalahan bahasa tulisan pada naskah dinas di Sekda Pemkot Mataram disebabkan berbagai faktor berikut.

1. Tidak Mengikuti Pedoman dalam Penyusunan Naskah Dinas

Penyusunan tatanaskah dinas di Sekda Pemkot Mataram pada dasarnya mengikuti ketentuan yang telah dibuat oleh Kementerian Dalam Negeri Republik Indonesia. Pedoman yang dibuat oleh Kemendagri tersebut menjadi acuan bagi pemerintah provinsi dan kabupaten kota di seluruh Indonesia, tidak terkecuali Pemerintah Kota Mataram beserta lembagalembaga yang berada di bawahnya. Dalam kenyataannya, pedoman yang dibuat oleh Kemendagri tersebut belum sepenuhnya diterapkan oleh bidangbidang yang ada di Sekda Pemkot Mataram. Dengan demikian, kesalahan berbahasa tulisan pada naskah dinas di Sekda Pemkot Mataram pun tidak dapat dihindari.

Lembaga-lembaga yang berada di bawah Sekda Pemkot Mataram 
terkadang secara langsung berhubungan dengan kementerian yang terkait dengan lembaga tersebut, misalnya, Bagian Hukum di Sekda Pemkot Mataram terkadang berinteraksi langsung dengan Kementerian Hukum RI. Interaksi langsung ini sedikit tidak berpengaruh pada model surat dinas yang dibuat. Dengan demikian, pedoman dari Kemendagri tidak jarang terabaikan.

2. Minimnya Pengetahuan Penyusun Naskah tentang Tata Bahasa Indonesia yang Sesuai dengan EYD

Kesalahan berbahasa tulisan dalam penyusunan naskah dinas di Sekda Pemkot Mataram juga terjadi karena kurangnya pengetahuan penyusun naskah kedinasan tentang kaidah bahasa Indonesia yang baik dan benar. Meskipun memiliki pedoman dari kementerian terkait, beberapa lembaga di bawah Sekda Pemkot Mataram juga menyusun naskah dinas atas inisiatif sendiri. Artinya, pedoman dari kementerian terkait diabaikan. Dengan demikian, kesalahan bahasa tulisan tidak dapat dihindari karena kurangnya pemahaman tentang aspek kebahasaan. Berdasarkan wawancara sekilas dengan staf pegawai bagian organisasi di Sekda
Pemkot Mataram, kebanyakan pegawai pada bagian tersebut tidak berlatar belakang pendidikan kebahasaan. Padahal, bagian organisasi merupakan bagian yang berperan besar dalam menyusun tata naskah dinas yang sifatnya internal lembaga.

\section{Pengaruh Bahasa Daerah}

Bahasa daerah sebagai bahasa pertama memiliki peran yang cukup besar terhadap penggunaan bahasa kedua. Para pakar pembelajaran bahasa kedua pada umumnya percaya bahwa bahasa pertama (bahasa ibu atau bahasa yang lebih dulu diperoleh) mempunyai pengaruh terhadap proses penguasaan bahasa kedua (Chaer, 2003). Pengaruh bahasa daerah dapat terlihat pada bahasa lisan maupun bahasa tulisan. Dalam naskah dinas di Sekda Pemkot Mataram, pengaruh bahasa daerah ini terlihat pada susunan pola kalimat bahasa Indonesia yang dibuat.

\section{Penutup}

Berdasarkan uraian pembahasan di atas, dapat ditarik dua simpulan terkait dengan kesalahan berbahasa pada naskah dinas di lingkungan Sekda Pemkot Mataram, yaitu: (a) sebaran kesalahan berbahasa tulisan pada 
naskah dinas di Sekda Pemkot Mataram dan (b) faktor-faktor penyebab terjadinya kesalahan bahasa tulisan pada naskah dinas di lingkungan Sekda Pemkot Mataram.

1. Sebaran kesalahan berbahasa tulisan pada Naskah Dinas di lingkungan Sekda Pemkot Mataram meliputi

1) kesalahan berbahasa ragam tulisan pada tataran penerapan EYD, misalnya penggunaan huruf kapital, tanda titik, tanda koma, dan huruf miring;

2) kesalahan berbahasa ragam tulisan pada tataran morfologi;

3) kesalahan berbahasa ragam tulisan pada tataran sintaksis; dan

4) kesalahan berbahasa ragam tulisan pada tataran semantik.

2. Faktor-Faktor penyebab kesalahan bahasa tulisan pada naskah dinas di lingkungan Sekda Pemkot Mataram adalah

1) penyusunan tata naskah dinas di lingkungan Sekda Pemkot Mataram belum mengikuti pedoman dari kementerian dalam negeri Republik Indonesia;

2) minimnya pengetahuan penyusun naskah tentang tata bahasa
Indonesia yang sesuai dengan EYD; dan

3) adanya pengaruh bahasa daerah ketika penyusunan kalimat dalam tata naskah dinas di lingkungan Sekda Pemkot Mataram.

\section{Daftar Pustaka}

Akmaluddin. (2014). Analisis Kesalahan Bahasa Tulisan pada Naskah Dinas di Sekretariat Daerah Pemkot Mataram dan Relevansinya terhadap Pembelajaran Bahasa Indonesia pada Jenjang Pendidikan Menengah. (Tesis tidak diterbitkan). Universitas Mataram, Mataram.

Alwi, Hasan dkk. (2003). Tata Bahasa Baku Bahasa Indonesia. Jakarta: Balai Pustaka.

Arifin, E. Zainal dan Hadi, Farid. (2009). 1001 Kesalahan Berbahasa. Jakarta: Akademika Pressindo.

Arikunto, Suharsimi. (2013). Prosedur Penelitian Suatu Pendekatan Praktik. Jakarta: Rineka Cipta.

Chaer, Abdul. (2002). Pengantar Semantik Bahasa Indonesia. Jakarta: Reineka Cipta.

Djago, Tarigan dan Sulistyaningsih, Lilis Siti. 1998. Analisis Kesalahan Berbahasa. Jakarta: Departemen 
Pendidikan dan Kebudayaan

Direktorat Jenderal Pendidikan

Dasar dan Menengah

Haimun. (2014). Penggunaan Bahasa

Indonesia dalam Karya Tulis

Ilmiah Guru Pembina Golongan

IV/a dan Pembelajarannya di

Sekolah Menengah Atas di Kota

Mataram Tahun 2013. (Tesis tidak

diterbitkan). Universitas Mataram,

Mataram.

Ramlan, M.. (2001). Morfologi Suatu

Tinjauan Deskriptif. Yogyakarta: CV. Karyono.

Sabariyanto, Dirgo. (2001). Mengapa

Disebut Kata Baku dan Tidak

Baku. Jakarta: Mitra Gama Media.

Setyawati, Nanik. (2010). Analisis

Kesalahan Berbahasa Indonesia

Teori dan Praktik. Surakarta: Yuma Pustaka.

Shalima, Irsyadi dkk. (2013). Detik-

Detik Ujian Nasional Bahasa

Indonesia. Klaten: PT Intan

Pariwara.

Tim Penyusun Kamus Pusat Bahasa. (2008). Kamus Bahasa Indonesia.

Jakarta: Pusat Bahasa. 